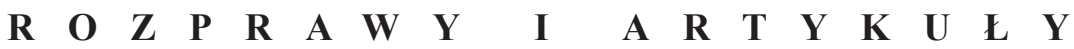

Prawo Kanoniczne

$56(2013) \mathrm{nr} 1$

O. PIOTR SKONIECZNY OP

Uniwersytet Papieski Św. Tomasza z Akwinu Angelicum, Rzym

\title{
KONCEPCJA PRZEDAWNIENIA KANONICZNEGO. UWAGI PRAWNOPORÓWNAWCZE I TEORETYCZNOPRAWNE DO KAN. 197 KPK (KAN. 1540 KKKW), ZE SZCZEGÓLNYM UWZGLEDNIENIEM KANONIZOWANEJ USTAWY POLSKIEJ
}

Treść: Wstęp: uwagi metodologiczne. - 1. Terminologia: przedawnienie czy...? - 1.1. Dawność w doktrynie polskiego prawa cywilnego. - 1.2. Praescriptio (przedawnienie) w prawie kanonicznym. - 1.3. Polski język prawny i prawniczy a polski język kanoniczny i kanonistyczny: między dawnościa a przedawnieniem. 2. Konstrukcja prawna. - 2.1. Marzenie o koncepcji ogólnej przedawnienia w nauce prawa - zrealizowana idea w prawie kanonicznym? - 2.2. Model dawności w prawie cywilnym polskim. - 2.3. Model przedawnienia kanonicznego w kan. 197 KPK (kan. $1540 \mathrm{KKKW})$ na tle prawnoporównawczym. - 2.3.1. Założenia idealne modelu. 2.3.2. Trudności z zastosowaniem teoretycznych założeń modelowych. - 2.3.3. Wnioski. - 3. Uzasadnienie legislacyjne przedawnienia kanonicznego na podstawie kan. 197 KPK (kan. 1540 KKKW). - Zakończenie.

\section{Wstęp: uwagi metodologiczne}

Przedstawienie koncepcji przedawnienia kanonicznego w sposób konieczny domaga się konfrontacji z innymi systemami prawnymi, świeckimi. Instytucja przedawnienia kanonicznego bowiem odwołuje się do prawa państwowego obowiązującego w danym miejscu (czyli „kanonizuje” to prawo ${ }^{1}$ ). To zagadnienie bardzo wiekowe w prawie

${ }^{1}$ Kanonizacja ustawy cywilnej oznacza uznanie normy prawa świeckiego za obowiązującą na forum kanonicznym; por. R. SobAŃski, Komentarz do kan. 22, w: J. Krukowski, R. Sobański, Komentarz do Kodeksu Prawa Kanonicznego, t. I: Księga I. 
kanonicznym. Problem zaś relacji z porządkiem prawnym świeckim w przypadku przedawnienia w prawie kanonicznym został dostrzeżony już w tzw. epoce klasycznej² przedkodeksowego prawa kanonicznego ${ }^{3}$.

Pomimo tak wielowiekowej tradycji kanonistycznej w literaturze kanonistycznej polskiej zagadnienie przedawnienia kanonicznego jest traktowane szczątkowo, a wspomina się o nim tylko fragmentarycznie przy okazji wydawania komentarzy do całego Kodeksu ${ }^{4}$. Nie ma żadnych opracowań monograficznych na ten temat, co zresztą odpowiada nurtowi w kanonistyce powszechnej po promulgacji Kodeksu Prawa Kanonicznego z 1983 r. ${ }^{5}$. Stąd też warto poświęcić temu zagadnieniu parę uwag z punktu widzenia kanonisty polskiego, tym bardziej że pojawiający się przy tej okazji problem relacji do prawa świeckiego (w tym przypadku polskiego) jest ciągle aktualny.

Pragnąc zaś doprecyzować obszar zainteresowań badawczych podjętych w tym artykule, należy z góry zauważyć, że chodzi jedynie o koncepcję, model teoretycznoprawny podobnych instytucji prawnych w dwóch różnych systemach prawnych. Oczywiście, opis ten wymaga przedstawienia różnych instytucji prawnych (przedawnienia kanonicz-

Normy ogólne, red. J. Krukowski, Poznań 2003, s. 77, t. 1, 3. Zob. również V. DE PAolis, I beni temporalni della Chiesa, Bologna 1995, s. 32-35.

${ }^{2}$ Chodzi o lata 1234 (promulgacja Dekretałów przez Grzegorza IX) - 1348 (śmierć Jana Andrzejowego, mistrza dekretalistów tego okresu, zmarłego na skutek epidemii tzw. czarnej śmierci, szalejącej wtedy w Europie). Okres ten został określony jako III etap rozwoju kanonistyki; por. A. VAN Hove, Prolegomena ad Codicem Iuris Canonici, Mechliniae - Roma 1945, s. 409-411; z pewną korektą P. ERDö, Storia della scienza del diritto canonico. Una introduzione, Roma 1999, s. 2-5.

3 Por. R. H. Helmholz, The Spirit of Classical Canon Law, Athens-London 1996, s. 190 .

4 Por. T. Pawluk, Prawo kanoniczne wedtug Kodeksu Jana Pawła II, t. I: Zagadnienia wstępne i normy ogólne, Olsztyn 2002, s. 287-291; R. SoBAŃSKI, Komentarz do kan. 197-199..., s. 286-291.

5 Kanonistyka światowa o wiele bardziej interesowała się przedawnieniem kanonicznym pod rządem Kodeksu z 1917 r. Nie tylko pojawiły się opracowania dotyczące przedawnienia, ale również komentowano poszczególne zagadnienia związane z tą instytucją, zwłaszcza pojęcie tzw. dobrej wiary. Natomiast pod rządem Kodeksu z 1983 r. zainteresowanie przedawnieniem kanonicznym nagle zgasło. 
nego i odpowiadających mu instytucji polskiego prawa cywilnego), ale przedstawienie to, siłą rzeczy, nie może być zbyt szczegółowe.

Specyfika prawa kanonicznego (por. kan. 6 \$2 KPK ${ }^{6}$ ) i jego wielowiekowa tradycja nakazuje odnieść się niekiedy (zwykle w przypisach) do korzeni historycznych przedawnienia kanonicznego, samo studium jednak nie ma charakteru historyczno-prawnego.

Głównym przedmiotem odniesienia jest prawo polskie. Jednakże powszechny charakter Kościoła katolickiego i jego prawa domagają się niekiedy ujęcia zagadnienia na tle prawnoporównawczym. Stąd też poczynione zostały szersze uwagi komparatystyczne, wykraczające poza obszar prawa polskiego, a to w celu lepszego zrozumienia relacji (zwłaszcza z punktu widzenia prawa kanonicznego) między obu porządkami prawnymi w zakresie analizowanych instytucji prawnych. Ten wymiar komparatystyczny jest usprawiedliwiony w sposób szczególny w przypadku obecnie obowiązującego, kanonizowanego przez ustawodawcę kościelnego, prawa polskiego, które przecież wywodzi się z tradycji romanistycznej i germańskiej. Ponadto nie da się zarysować modelu teoretycznego przedawnienia kanonicznego bez poznania innych możliwych rozwiązań, a to wobec powszechnego charakteru prawa kanonicznego, a co za tym idzie jego bogatego doświadczenia styku z innymi systemami państwowymi. Stąd wzięcie jedynie prawa polskiego za punkt odniesienia, by zbudować model teoretycznoprawny przedawnienia kanonicznego, byłoby błędne metodologicznie. Doświadczenie prawa kanonicznego, jeżeli chodzi o kanonizację, jest bowiem o wiele bogatsze i wykracza poza prawo polskie.

\footnotetext{
${ }^{6}$ Przepis ten brzmi następująco: „Canones huius Codicis, quatenus ius vetus referunt, aestimandi sunt ratione etiam canonicae traditionis habita”, czyli w thumaczeniu polskim: „Jeśli kanony niniejszego Kodeksu zawierają stare prawo, winny być interpretowane z uwzględnieniem również kanonicznej tradycji”. Ponadto por. odpowiednio kan. 2 KKKW. W tekście skróty KPK i KKKW oznaczają odpowiednio: Kodeks Prawa Kanonicznego oraz Kodeks Kanonów Kościołów Wschodnich. Przekład polski KPK wg: Codex Iuris Canonici auctoritate Ioannis Pauli PP. II promulgatus. Kodeks Prawa Kanonicznego. Przekład polski zatwierdzony przez Konferencję Episkopatu, Poznań 1984.
} 
W końcu należy zauważyć, że wyłączono z pola zainteresowania przedawnienie kanoniczno-karne ${ }^{7}$. Jeżeli chodzi o przedawnienie kanoniczno-karne, to w tym zakresie nie jest możliwa kanonizacja ustawy cywilnej, a stąd i jakakolwiek relacja do tej ustawy. Tymczasem jednym z celów niniejszego artykułu jest ,szczególne uwzględnienie kanonizowanej ustawy polskiej”. Ponadto trzeba zaznaczyć, że instytucja przedawnienia kanonicznego - jakkolwiek obejmuje także przedawnienie kanoniczno-karne, o czym będzie mowa niżej - to jednak wykazuje wyraźne różnice pomiędzy przedawnieniem karno-kanonicznym i przedawnieniem kanonicznym ,cywilnym”. Różnice te ujawniają się nie tylko na płaszczyźnie formalnoprawnej, ale też na podłożu uzasadnienia prawnego samej instytucji przedawnienia kanonicznego, stanowiąc o odrębności przedawnienia karno-kanonicznego ${ }^{9}$. Stąd też zagadnienie to wymaga odrębnego opracowania i nie jest przedmiotem niniejszych rozważań.

\section{Terminologia: przedawnienie czy...?}

\subsection{Dawność w doktrynie polskiego prawa cywilnego}

Polska doktryna prawa cywilnego, a co za tym idzie - język polski prawniczy, zna pojęcie dawności. Termin ten jest pochodzenia staropolskiego i obejmuje wszystkie instytucje prawne, dotyczące upływu czasu jako zdarzenia prawnego. Ten upływ czasu w dawności jest konieczną, ale nie jedyną przesłanką wywołania wskazanych skutków prawnych. Do tych instytucji prawnych zalicza się: przedawnienie, terminy zawite, zasiedzenie, oraz tzw. przemilczenie ${ }^{10}$. Instytucje te należy od siebie pojęciowo rozgraniczyć.

7 Inaczej, por. R. Sobański, Komentarz do kan. 197-199..., s. 288, t. 2 do kan. 197.

8 Por. Ph. J. Brown, Prescription and Statutes of Limitation, w: Canon Law Society of America Proceedings of the Seventieth Annual Convention, Kansas City, Missouri, October 13-16, 2008, Washington DC 2008, s. 398.

9 Zob. tamże, s. 430-440.

${ }^{10}$ Zob. B. Kordasiewicz, Problematyka dawności, w: System prawa prywatnego, red. Z. Radwański, t. 2: Prawo cywilne - część ogólna, red. Z. Radwański, Warszawa 2002, s. 529, nb. 2; Tenże, Prawo cywilne - część ogólna, Warszawa 1993, s. 221, nb. 698. 
Przedawnienie w prawie cywilnym polskim oznacza ograniczenie pod względem czasowym dochodzenia roszczenia majątkowego, jeżeli skutkiem upływu terminu jest tylko niemożność dochodzenia, a nie wygaśnięcie roszczenia ${ }^{11}$.

Od tego pojęcia należy odróżnić w polskim prawie cywilnym terminy zawite, zwane też prekluzyjnymi, które prowadzą do wygaśnięcia roszczenia lub prawa ${ }^{12}$.

Zasiedzenie z kolei to nabycie prawa rzeczowego wskutek faktycznego wykonywania tego prawa przez pewien, ustawowo określony, czas ${ }^{13}$. Zasiedzenie więc polega na $\mathrm{z}$ jednej strony nabyciu prawa przez nieuprawnionego posiadacza, a $\mathrm{z}$ drugiej - na utracie tegoż prawa przez dotychczas uprawnionego ${ }^{14}$. Zasiedzenie jest ,prawnym skutkiem posiadania"15, ale też i skutkiem upływu czasu. Z tego względu obejmuje się instytucję zasiedzenia zakresem pojęcia dawności.

Podobnie jak zasiedzenie instytucją prawa rzeczowego jest tzw. przemilczenie ${ }^{16}$. Istota przemilczenia sprowadza się do tego, że uprawniony,

${ }^{11}$ Por. B. Kordasiewicz, Problematyka dawności..., s. 534, nb. 15. Podobnie Z. RADWAŃSKI, Prawo cywilne..., s. 222-223, nb. 707-708.

${ }^{12}$ Por. Z. Radwański, Prawo cywilne..., s. 229, nb. 736.

${ }^{13}$ Por. E. JANECzKo, Zasiedzenie, Warszawa 1981, s. 5, a zwłaszcza powszechnie przyjmowane określenia zasiedzenia przez literaturę, na którą powołuje się Autor w przyp. 1. Zob. ponadto A. KunICKI, Zasiedzenie w prawie polskim, Warszawa 1964, s. 13, 35.

${ }^{14}$ Rzymianie podkreślali pozytywny charakter zasiedzenia (Modestinus: „Usucapio est adiectio dominii [podkr. moje - P. S.] per continuationem possessionis temporis lege definiti”). A. KunICKI, Zasiedzenie..., s. 13, przyp. 1.

15 Tamże, s. 13.

${ }^{16}$ Przykłady przemilczenia na gruncie prawa polskiego to chociażby przypadki z art. 187 Kodeksu cywilnego [dalej: k.c.] oraz art. 34 dekretu z dnia 8 marca 1946 o majątkach opuszczonych i poniemieckich (Dz. U. Nr 13, poz. 87 ze zm., uchylony: Dz. U. z 1985 r. Nr 22, poz. 99). Bliżej na ten temat: E. JANECzKo, Zasiedzenie..., s. 7-9 wraz z literaturą powołaną w przyp. 14; J. Ignatowicz, Prawo rzeczowe, Warszawa 1995, s. 112. Treść art. 187 k.c.: „Pieniądze, papiery wartościowe, kosztowności oraz rzeczy mające wartość naukową lub artystyczną, które nie zostaną przez uprawnionego odebrane w ciągu roku od dnia wezwania go przez właściwy organ, a w razie niemożności wezwania - w ciągu dwóch lat od ich znalezienia, stają się własnością Skarbu Państwa. Inne rzeczy stają się po upływie tych samych terminów własnością znalazcy, jeżeli uczynił on zadość swoim obowiązkom; jeżeli rzeczy są przechowywane przez organ państwowy, znalazca może je odebrać za zwrotem kosztów". Ze 
nie wykonując swego prawa, „milcząc”, traci to prawo. O ile więc przy zasiedzeniu dochodziło do nabycia prawa w wyniku aktywności zainteresowanego posiadacza, o tyle przy przemilczeniu skutek ten następuje wobec bierności uprawnionego ${ }^{17}$. Różne są też funkcje obu tych instytucji. $\mathrm{O}$ ile bowiem $\mathrm{z}$ reguły zasiedzenie będzie miało na celu usunięcie sprzeczności między stanem posiadania a stanem prawnym (w tzw. nieformalnym obrocie nieruchomościami), o tyle przemilczenie będzie niwelowało negatywne skutki tego typu sytuacji, w których właściciel nie interesuje się w ogóle swoją nieruchomością ${ }^{18}$.

Pojęcia przedawnienia i terminów zawitych można objąć wspólnym terminem przedawnienia umarzającego. Oznacza ono sytuacje, w których dochodzi do odmowy udzielenia ochrony podmiotowi dotychczas uprawnionemu ${ }^{19}$.

Natomiast w przypadku zasiedzenia i przemilczenia dochodzi do tzw. przedawnienia nabywczego. Zasiedzenie bowiem i przemilczenie prowadzą do nabycia praw podmiotowych i to o charakterze bezwzględnym (tj. praw rzeczowych, np. własności) przez dotąd nieuprawnionego. Podobnie jak przy przedawnieniu umarzającym odmawia się ochrony podmiotowi dotychczas uprawnionemu, ale brak tej ochrony jest wtórnym następstwem utraty samego prawa podmiotowego $^{20}$. Rozwijając tę myśl można powiedzieć, że w przypadku przedawnienia umarzającego występuje niejako skutek negatywny działania ustawy, podczas gdy przedawnienie nabywcze działa pozytywnie, powodując nabycie prawa podmiotowego ${ }^{21}$. Z kolei jeżeli chodzi o funkcje obu typów przedawnienia, to przedawnienie nabywcze reguluje głównie stosunki własnościowe, przedawnienie umarzające zaś umacnia dyscyplinę umowną i finansową, co też ma swoje odzwierciedlenie w długości

względu na marginalne znaczenie przemilczenia zostanie ono pominięte w głównym toku dalszych rozważaniach.

${ }^{17}$ Por. E. JaneczKo, Zasiedzenie..., s. 7 oraz Z. RAdwAŃsKi, Prawo cywilne..., s. 222, nb. 700-701.

${ }^{18}$ Zob. J. Ignatowicz, Prawo rzeczowe..., s. 107; E. Janeczko, Zasiedzenie..., s. 10.

${ }^{19}$ Zob. B. Kordasiewicz, Problematyka dawności..., s. 529, nb. 3.

${ }^{20}$ Por. tamże.

${ }^{21}$ Zob. Z. RadWAŃski, Prawo cywilne..., s. 222, nb. 704. 
terminów, które są znacznie dłuższe w wypadku przedawnienia nabywczego $^{22}$.

Polskie prawo cywilne nie stanowi definicji ustawowych przedawnienia, terminów zawitych czy przemilczenia. Natomiast podaje przesłanki zasiedzenia w art. 172 k.c. ${ }^{23}$, w ten sposób je definiując ${ }^{24}$. W języku prawnym polskim nie jest znane pojęcie przedawnienia umarzającego ani nabywczego, które występuje tylko w języku prawniczym ${ }^{25}$.

\subsection{Praescriptio (przedawnienie) w prawie kanonicznym}

Przedawnienie kanoniczne (praescriptio ${ }^{26}$ ) jest złożoną instytucją prawa kanonicznego, rozumianą jako sposób nabycia lub utraty szeroko pojętego prawa, a także uwolnienia się od zobowiązań, zgodnie z przepisami prawa (por. kan. $197 \mathrm{KPK}$ ), w oparciu o dobrą wiarę, z upływem wymaganego czasu (por. kan. 198 KPK) wobec przedmiotów ulegających przedawnieniu (por. kan. 199 KPK) ${ }^{27}$. Złożoność

${ }^{22}$ Konkretnie zaś zasiedzenia; por. art. 172 k.c. (terminy zasiedzenia 20- i 30-letni) $\mathrm{z}$ art. 118, art. $88 \mathrm{czy}$ też na przykład z art. 563 k.c. (odpowiednio: terminy przedawnienia 10- i 3-letni, roczny termin zawity i miesięczny termin zawity).

${ }^{23}$ Art. 172 - § 1. Posiadacz nieruchomości nie będący jej właścicielem nabywa własność, jeżeli posiada nieruchomość nieprzerwanie od lat dwudziestu jako posiadacz samoistny, chyba że uzyskał posiadanie w złej wierze (zasiedzenie).

${ }^{24}$ Jest to tzw. definicja nawiasowa, będąca ubocznym elementem przepisu merytorycznego. Przykład art. $172 \S 1$ k.c. jest podawany przez M. Zielińskiego; por. M. ZIELIŃSKI, Wykładnia prawa. Zasady. Reguły. Wskazówki, Warszawa 2002, s. 191, 193-194.

${ }^{25} \mathrm{O}$ tym rozróżnieniu zob. B. WRóBlewsKI, Język prawny i prawniczy, Kraków 1948. Język prawny to język przepisów prawnych, natomiast język prawniczy to język wypowiedzi o prawie.

${ }^{26}$ Termin praescriptio był też używany w języku kanonicznym na określenie przepisu prawnego; tak pod rządem KPK z 1917 r., por. K. MörsDORF, Die Rechtssprache des Codex Iuris Canonici, Paderborn 1967, s. 64. Obecnie, pod rządem KPK z 1983 r., zachowało się jego kolejne znaczenie prawnokarne „nakaz” (por. kan. $1336 \S 1,1^{\circ}$ oraz kan. 1337 § i 2).

${ }^{27}$ Zob. J. García Martín, Le Norme Generali del Codex Iuris Canonici, Roma 1999, s. 639. Podobnie por. C. Redaelli, Trascorrere del tempo, certezza del diritto e buona fede: la prescrizione, Quaderni di Diritto Ecclesiale 4(1991) nr 2, s. 225.

W literaturze kanonistycznej pod rządem KPK z 1983 r. proponowane były także inne definicje przedawnienia. 
Niezbyt jasna i niedoskonała jest definicja proponowana przez T. Pawluka, który określa przedawnienie jako ,[...] upływ czasu powodujący utratę dochodzenia cywilnego lub niemożność wszczęcia postępowania karnego" (T. PAwluk, Prawo..., s. 287). Następnie zaś rozwija on tę definicję: „W naszym przypadku chodzi o przedawnienie w zakresie spraw cywilnych. Określamy je jako sposób nabycia lub utraty prawa subiektywnego bądź uwolnienia się od roszczeń na skutek prawnie określonego upływu czasu"; por. tamże; podobnie zob. M. SitARz, Słownik prawa kanonicznego, Warszawa 2004, s. 144, hasło: przedawnienie. Polemizując z tą definicją, trzeba zauważyć, że instytucja przedawnienia nie wyczerpuje się tylko w upływie czasu, co sugeruje T. Pawluk, ale jest instytucją o wiele bardziej złożoną, m.in. przez konieczność wystąpienia innych przesłanek (np. dobrej wiary według ustawodawstwa kanonicznego, na co słusznie zwracają uwagę: J. García Martín, Le Norme Generali..., s. 640; F. J. URrutia, Les Normes Générales. Commentaire des canons 1-203, Paris 1994, s. 263, nb. 930). Zupełnie niejasny jest termin ,utraty dochodzenia cywilnego": czy chodzi o utratę roszczenia? Jeśli tak, to jakiego roszczenia - procesowego czy materialnoprawnego?

Wydaje się, że podobne ograniczenia ma definicja przedawnienia proponowana przez V. De Paolis i A. D’Auria, którzy definiują przedawnienie jako: ,[...] instytucję prawa kanonicznego pozytywnego, na mocy której podmiot, wskutek upływu czasu, nabywa [...] lub traci na rzecz osoby trzeciej pewne prawo rzeczowe albo też - zawsze na skutek upływu czasu - następuje wygaśnięcie prawa wierzyciela"; por. V. DE PAoLis, A. D’Auria, Le Norme Generali. Commento al Codice di Diritto Canonico. Libro Primo, Città del Vaticano 2008, s. 493. Ci Autorzy z kolei zawężają definicję przedawnienia kanonicznego do spraw cywilnych, co jest sprzeczne z kan. 198 KPK, który wprost odwołuje się do przedawnienia karno-kanonicznego.

Wydaje się, że z podobnymi ograniczeniami - jakkolwiek w nieco ograniczonym zakresie - boryka się definicja podana przez Urrutię, który określa przedawnienie jako „[...] instytucję, stworzoną przez prawo pozytywne, która ma na celu przeniesienie prawa (niekoniecznie dotyczącego dóbr doczesnych) z jednego podmiotu na drugi, wskutek posiadania trwającego w czasie". Por. F. J. URrutia, Les Normes Générales..., s. 263 , nb. 930 .

Z tych względów bliższą proponowanemu określeniu przedawnienia w polskiej literaturze kanonistycznej jest definicja zaproponowana przez R. Sobańskiego: „Przedawnienie to następujący przez upływ czasu sposób nabycia lub utraty rzeczy lub praw, a także uwolnienia się od obowiązków czy roszczeń"; por. R. SoBAŃSKI, Komentarz do kan. 197-199..., s. 286. W tym samym tonie wypowiedział się J. MiñAmbres, Komentarz do kan. 197-199, w: Exegetical Commentary on the Code of Canon Law: prepared under the responsability of the Martín de Azpilcueta Institute Faculty of Canon Law University of Navarre, red. A. Marzoa, J. Miras, R. Rodríguez-Ocaña, t. I, Montreal-Chicago 2004, s. 1083. Jednakże i te propozycje nie są pozbawione braków, gdyż nie dostrzegają, że przedawnienie kanoniczne nie ogranicza się tylko do upływu czasu.

Stąd niekiedy Autorzy dodali do tego typu definicji, słusznie zresztą, określenie: 
przedawnienia kanonicznego wynika z tego, że instytucja ta dotyczy nie tylko skutków cywilnoprawnych upływu czasu (jak w instytucji dawności w prawie polskim), ale również odnosi się do przedawnienia karno-kanonicznego czy skutków upływu czasu w prawie administracyjnym kanonicznym ${ }^{28}$. Regulacja przedawnienia kanonicznego nie ogranicza się jedynie do Tytułu X Księgi I KPK (kan. 197-199) czy rozdziału I Tytułu XXX KKKW (kan. 1540-1542), ale jest rozproszona po całym Kodeksie ${ }^{29}$.

Niezależnie jednak od tej złożoności przedawnienia kanonicznego, w literaturze przedmiotu ${ }^{30}$ proponuje się inną definicję tej instytucji prawnokanonicznej. Cytując ustawodawcę kościelnego z kan. 197 KPK, przedawnienie to „sposób nabycia lub utraty prawa podmioto-

"pod warunkami ustanowionymi przez prawo". Por. R. T. Kennedy, Komentarz do kan. 197-203, w: New Commentary on the Code of Canon Law, red. J. P. Beal, J. A. Coriden, Th. J. Green, New York 2000, s. 230. Podobnie E. Molano, Komentarz do kan. 197, w: Codex Iuris Canonici. Kodeks Prawa Kanonicznego. Komentarz, red. Instytut Martín de Azpilcueta, red. wyd. pol. P. Majer, Kraków 2011, s. 195 (zapominając jednak o uwzględnieniu elementu upływu czasu).

${ }^{28}$ Jak podnosi się w kanonistyce, przedawnienie kanoniczne może nawet dotyczyć urzędu kościelnego w rozumieniu subiektywnym; por. H. PreE, Diritto consuetudinario - un modo per creare uffici di laici?, Archiv für katholisches Kirchenrecht 177(2008), nr 1, s. 17, 25. Co do innych przedmiotów przedawnienia kanonicznego zob. kan. 199 KPK (kan. 1542 KKKW). Tę złożoność przedawnienia kanonicznego podkreśla bardzo dobitnie w literaturze kanonistycznej Рн. J. BRown, Prescription..., s. $398,436$.

${ }^{29}$ Por. kan. 82, 1268, 1269, 1270, 1344 n. 3, 1362, $1492 \S 1$ i 2, 1512 n. 4, 1720 n. 3, 1726 KPK oraz - odpowiednio - kan. 1534, 1017, 1018, 1019, 1409 §2 n. 4, 1152, 1150, 1151, 1194 n. 5, 1482 KKKW.

${ }^{30}$ Por. E. Turnaturi, Dispense Causae Iurium, Pontificia Università S. Tommaso d'Aquino Angelicum, r. akad. 2008/2009, s. 78. Tak samo P. V. Pinto, Komentarz do kan. 197-199, w: Commento al Codice di Diritto Canonico, red. P. V. Pinto, Città del Vaticano 2001, s. 107. Podobnie zresztą, jakkolwiek dostosowując do kontekstu prawa cywilnego niemieckiego, W. Aymans, K. MörSDorf, Kanonisches Recht. Lehrbuch aufgrund des Codex Iuris Canonici, t. I: Einleitende Grundfragen und Allgemeine Normen, Paderborn 1991, s. 503. Autorzy ci odróżniają przedawnienie w znaczeniu szerokim, definiując je jako: „,...] instrument [prawny] służący podmiotowi w celu nabycia prawa lub też uwolnienia się od roszczeń prawnych". 
wego, jak również uwolnienia się od zobowiązań"31. W ten sposób w doktrynie prawa kanonicznego zauważono, że definicja przedawnienia została zawarta w samej ustawie kościelnej, a mianowicie w kan. 197 KPK (kan. 1540 KKKW). Co więcej, definicja ta byłaby zupełna, jako że obejmowałaby nie tylko przedawnienie nabywcze, ale i umarzające ${ }^{32}$.

Należy rozważyć tę sugestię kanonistyki, że chodzi o definicję ustawową przedawnienia. W rzeczy samej, kontekst bliższy słowa praescriptionem w kan. 197 KPK, czyli słowa oddzielone przecinkami, niejako definiujące to słowo - zdają się przemawiać za tego typu rozumowaniem, tym bardziej że chodzi o przepis umieszczony w Normach ogólnych Kodeksu ${ }^{33}$. Nie jest to jednak definicja ustawowa przedawnienia.

Przede wszystkim przeczą tej tezie zasady techniki legislacyjnej. Definicja legalna ma dwie cechy - występuje w tekście jakiegoś aktu prawnego i odnosi się do jakiegoś zwrotu językowego występującego w tym właśnie akcie ${ }^{34}$. Jeżeli chodzi o pierwszą cechę, przedawnienie, o którym mowa w kan. 197 KPK, odsyła do ustawodawstwa państwowego w tym zakresie, a nie do KPK, jak to powinna czynić definicja ustawowa. Z kolei co do drugiej cechy należy stwierdzić, że tak pro-

${ }^{31} \mathrm{~W}$ tekście przekład oficjalny poprawiony przez Autora. W oryginale: "Praescriptionem, tamquam modum iuris subiectivi acquirendi vel amittendi necnon ab obligationibus sese liberandi, [Ecclesia recipit...]". Podobne sformułowanie - z kilkoma zmianami redakcyjnymi o charakterze czysto technicznym (szyk zdania) - zostało użyte w kan. 1540 KKKW.

${ }^{32}$ Por. E. Turnaturi, Dispense..., s. 78-79: "La definizione è completa, perché abbraccia la prescrizione nei suoi vari aspetti: prescrizione acquisitiva [...]; [prescrizione] estintiva". Podobnie, wprost o definicji przedawnienia w kan. 197 KPK, por. F. PoTOTSCHING, Rechtspersönlichkeit und rechtserhebliches Geschehen, w: Handbuch des katholischen Kirchenrechts, red. J. Listl, H. Schmitz, Regensburg 1999, s. 148 wraz z przyp. 41; R. Sobański, Komentarz do kan. 197..., s. 287, t. 1 („Przepisy dotyczące przedawnienia zaczynają się od - wtrąconej w normę - definicji przedawnienia" - kursywa P.S.).

${ }^{33}$ Co z kolei wskazywałoby na drugi typ definicji ustawowej: nie „nawiasową” czy „słowniczkową”, ale umieszczoną w tekście prawnym, zazwyczaj w przepisach ogólnych. Por. M. ZIELIŃsKi, Wykładnia prawa..., s. 193.

${ }^{34}$ Zob. tamże, s. 188. 
ponowana definicja (,sposób nabycia lub utraty prawa podmiotowego, jak również uwolnienia się od zobowiązań”) byłaby błędna, biorąc pod uwagę, że dotyczy ona nie tylko praw podmiotowych, ale również przedawnienia karnego w kan. 1362 i 1363 KPK $^{35}$. Stąd może z tych względów ustawodawca kościelny poprawił tekst łaciński w KKKW, usuwając wyodrębnienie „definicji” przecinkami i zmieniając szyk zdania $^{36}$.

Tezie, że w kan. 197 KPK (kan. 1540 KKKW) jest zawarta definicja ustawowa przedawnienia kanonicznego, przeczy ponadto argument z wykładni systemowej. Termin praescriptio, którym posługuje się ustawodawca kościelny, aby nazwać Tytuł X Księgi I KPK, obejmuje szereg sytuacji prawnych, nie ograniczając się do sytuacji nazwanych w kan. 197 KPK. Obok wspomnianego przedawnienia karnego, wzmiankowanego też w kan. 198 KPK, trzeba wskazać na kan. 199 KPK, który dotyczy szeregu hipotez, jakie nie są możliwe do objęcia kan. 197 KPK.

W końcu, cechą charakterystyczną nauki prawa kanonicznego jest ukazywanie elementów pojedynczych, aby wydobyć istotę pojęcia ${ }^{37}$. Ustawodawca kościelny unika bowiem definicji, skoro omnis definitio in iure periculosa est. Biorąc pod uwagę technikę legislacyjną, można opisać rzeczywistość poprzez wskazanie jej cech, niekoniecznie posługując się metodą definicji ${ }^{38}$.

Wydaje się, że właśnie do takiego opisu - poprzez wskazanie pewnych cech, bez definiowania - uciekł się ustawodawca kościelny w kan. 197 KPK. Miał bowiem na względzie bogactwo regulacji cywilnoprawnych szeregu ustawodawstw państwowych. Rzeczywistość opisał jak najszerzej, bo taki był cel normy kanonizującej prawo cy-

${ }^{35}$ Na słabość koncepcji prawa podmiotowego w odniesieniu do przedawnienia karno-kanonicznego wskazuje PH. J. Brown, Prescription ..., s. 431.

${ }^{36} \mathrm{~W}$ oryginale kan. $1540 \mathrm{KKKW}$ (zmiany zaznaczone pokreśleniami): „Praescriptionem_tamquam iuris subiectivi acquirendi vel amittendi necnon ab obligationibus se liberandi modum, prout est in iure civili, Ecclesia recipit, nisi aliud iure communi statuitur".

${ }^{37}$ Por. G. MAY, A. EgLER, Einführung in die kirchenrechtliche Methode, Regensburg 1986, s. 118.

${ }^{38}$ Zob. tamże, s. 117. 
wilne w kan. 197 KPK: trzeba było wziąć pod uwagę różne modele prawne przedawnienia w obowiązującym i w możliwym w przyszłości prawie cywilnym na całym świecie, gdzie Kościół katolicki działa.

Niezależnie od tego, że język kanoniczny posługuje się terminem praescriptio, język kanonistyczny ${ }^{39}$ używa też terminów praescriptio acquisitiva (usucapio) i praescriptio extinctiva seu liberativa ${ }^{40}$. Odpowiadają one pojęciom przedawnienia nabywczego (zasiedzenia) i przedawnienia umarzajacego w doktrynie prawa cywilnego polskiego, o czym była już mowa wyżej.

\subsection{Polski język prawny i prawniczy a polski język kanoniczny i ka- nonistyczny: między dawnościa a przedawnieniem}

Terminologia kanoniczna i terminologia polska w przedmiocie szeroko pojętego przedawnienia nie są „kompatybilne”. Z jednej strony

${ }^{39} \mathrm{O}$ rozróżnieniu języka kanonicznego, czyli kanonów albo przepisów prawa kościelnego, oraz kanonistycznego, tj. kanonistyki - por. R. SoBAŃsKI, Eklezjologia nowego Kodeksu Prawa Kanonicznego, Prawo Kanoniczne 28(1985), nr 1-2, s. 5; P. KROCZEK, Zasada „clara non sunt interpretanda” w prawie kanonicznym, Kraków 2005, s. 68, przyp. 26.

${ }^{40}$ Zob. na przykład: H. SochA, Komentarz do kan. 197-199, w: Münsterischer Kommentar zum Codex Iuris Canonici, red. K. Lüdicke, Loseblattwerk, Stand: Juli 1993, Essen 1984-, Einführung vor 197/1, t. 1, 197/1, t. 4 i 5; F. Рототsching, Rechtspersönlichkeit..., s. 148; E. Molano, Komentarz..., s. 195; E. Turnaturi, Dispense..., s. 78-79; J. García Martín, Le Norme Generali..., s. 640; V. De Paolis, A. D’Auria, Le Norme Generali..., s. 493; C. Redaeldi, Komentarz do kan. 197-199, w: Codice di Diritto Canonico commentato, red. Redazione di „Quaderni di diritto ecclesiale”, Milano 2009, s. 216. W niemieckiej literaturze kanonistycznej odróżnia się odpowiednio przedawnienie w znaczeniu szerokim (Verjährung i.[m] w.[eiteren] S.[inne]), które obejmuje także zasiedzenie (Ersitzung). Od tego należy odróżnić przedawnienie w znaczeniu ścisłym (Verjährung i.[m] e.[ngeren ] S.[inne]), czyli przedawnienie umarzające, określane po łacinie terminem praescriptio extinctiva seu liberativa. Praktycznie zatem przedawnienie w znaczeniu szerokim obejmuje tak przedawnienie nabywcze, jak i przedawnienie umarzające. Natomiast przedawnienie w znaczeniu ścisłym dotyczyłoby tylko przedawnienia umarzającego. Por. K. Mörsdorf, Die Rechtssprache..., s. 265; H. Socha, Komentarz do kan. 197-199..., l. cit.; W. Aymans, K. Mörsdorf, Kanonisches Recht..., s. 503, ale też A. Stankiewicz, De „,canonizatione" decadentiae legali in ambitu praescriptionis extinctivae in iure canonico, Periodica de re morali, canonica, liturgica 75(1986), nr 1-2, s. 337-338. 
język polski prawniczy (ale też prawny) jest o wiele bogatszy niż słownictwo języka kanonicznego (i kanonistycznego). Z drugiej zaś strony instytucje, o których mowa, różnią się od siebie w wielu miejscach, o czym będzie mowa niżej ${ }^{41}$. Trzeba poczynić przynajmniej dwie obserwacje wstępne.

Przede wszystkim łacińskie praescriptio, użyte w kan. 197 KPK i $1540 \mathrm{KKKW}$, nie jest tym samym, czym polskie słowo przedawnienie, zastosowane w oficjalnym tłumaczeniu KPK z 1983 r. Jak już bowiem zauważono, kanonizacja ustaw cywilnych dotyczy takich i tylko takich instytucji prawa cywilnego, które wskutek upływu czasu powodują utratę prawa podmiotowego lub też uwolnienie się od zaciągniętych zobowiązań, przy czym zakres tej kanonizacji obejmuje wszystkie tego typu instytucje prawa cywilnego danego państwa. A zatem w thumaczeniu kan. 197 KPK właściwszym by było oddanie słowa łacińskiego praescriptio polskim terminem dawność. Dawność bowiem - jak to wspomniano - dotyczy przedawnienia, terminów zawitych, zasiedzenia i przemilczenia, tj. tych właśnie instytucji, o które chodziło ustawodawcy kościelnemu.

W tym miejscu należy jednak dokonać kolejnej uwagi krytycznej. Ustawodawca kościelny wszakże nie ograniczył pojęcia praescriptio tylko do instytucji o charakterze cywilnoprawnym. Jak bowiem wynika z kan. 198 i 199 KPK (oraz odpowiednio kan. 1541 i 1542 KKKW), a także z samego zatytułowania Tytułu X Księgi I KPK (rozdziału I Tytułu XXX KKKW) - praescriptio rozciąga się też na działanie czasu w całym porządku prawnokanonicznym (też w prawie karnym kanonicznym czy w prawie administracyjnym kanonicznym). Tak szerokiego zakresu nie ma termin dawności, który przecież dotyczy tylko

\footnotetext{
${ }^{41}$ Jest to także problem kanonistyki w innych miejscach, jak choćby w kręgu kultury prawnej germańskiej czy anglosaskiej. W Stanach Zjednoczonych Ameryki Północnej na przykład pojęciu praescriptio odpowiadają trzy inne terminy: adverse possession (odpowiadające polskiemu zasiedzeniu praw rzeczowych), prescription (dotyczy wygasania praw osobistych) oraz statute of limitations (przedawnienie); por. TH. O. Martin, Adverse Possession, Prescription and Limitation of Actions. The Canonical “Praescriptio". A Commentary on Canon 1508, Washington 1944, s. XIX, 3-4; R. T. Kennedy, Komentarz ..., s. 230; PH. J. Brown, Prescription..., s. 384-388, 398-399.
} 
dziedziny prawa cywilnego. Co więcej, bodaj żaden system prawny obecnie obowiązujący nie zna pojęcia typu kanonicznego praescriptio, które by miało znaczenie ogólne i dotyczyło całego systemu prawnego $^{42}$. Konsekwentnie zatem jedynie w kan. 197 KPK (kan. 1540 KKKW) praescriptio mogłoby być przetłumaczone jako dawność, gdyż tylko w tym miejscu mowa jest o instytucjach kanonizowanego prawa cywilnego ${ }^{43}$.

To jednak naraziłoby na szwank spójność tłumaczenia, gdyż w pozostałych miejscach (np. w tytule czy w kanonach następujących) praescriptio trzeba by było oddać innym słowem - z braku lepszego na przykład: przedawnienie. A zatem to samo słowo łacińskie praescriptio można by przełożyć na język polski różnorodnie w różnych miejscach KPK, gdyż niekompatybilność języków prawnych i prawniczych łacińskiego i polskiego wywodzi się z niekompatybilności obu systemów prawnych - kanonicznego i polskiego.

Wydaje się wszakże, że lepiej unikać przekładu tego samego wyrażenia w języku oryginalnym różnymi terminami w języku tłumaczenia. Chodzi o to, by jak najlepiej przełożyć myśl ustawodawcy z języka oryginalnego. Skoro zaś ustawodawca używał tego samego terminu w różnych sytuacjach i kontekstach, trzeba to uszanować w tłumaczeniu.

Przełożenie jednak słowa praescriptio terminem przedawnienie też nie jest najlepsze, gdyż w języku polskim prawnym i prawniczym ma ono swoje określone znaczenie.

$\mathrm{Z}$ podobnymi dylematami boryka się niemiecka literatura kanonistyczna, która ma podobny system prawa cywilnego do obowiązującego w Polsce. Stąd z zainteresowaniem trzeba przyjąć propozycję kano-

\footnotetext{
${ }^{42}$ Por. B. Kordasiewicz, Problematyka dawności..., s. 528-529, nb. 1. W kontekście kultury prawnej anglosaskiej na ten sam problem wskazuje PH. J. Brown, Prescription..., passim, a zwłaszcza s. 398.

${ }^{43}$ Tak na przykład w tłumaczeniu niemieckim KPK, w którym to praescriptio w kan. 197, 198 i 199 oraz w tytule Tytułu X Księgi I KPK zostało przetłumaczone jako Ersitzung und Verjährung (zasiedzenie i przedawnienie - w języku niemieckim brak jednolitego terminu odpowiadającemu polskiemu pojęciu dawności). Por. Codex des kanonischen Rechts. Lateinisch-deutsche Ausgabe mit Sachverzeichnis, Kevelaer 2001, s. 81 .
} 
nistyki niemieckiej ${ }^{44}$, która zrezygnowała $\mathrm{z}$ thumaczenia praescriptio $\mathrm{i}$ termin ten po prostu zniemczyła jako Präskription. Zmierzająca się $\mathrm{z}$ tym samym problemem literatura kanonistyczna na gruncie anglosaskim zostawia po prostu termin w lacińskim, oryginalnym brzmieniu ${ }^{45}$.

Na gruncie polskim można by również tłumaczyć praescriptio jako preskrypcję, by w ten sposób ukazać, że nie chodzi tylko o przedawnienie w rozumieniu polskiego prawa cywilnego. W końcu wydaje się, że można też zaproponować inne thumaczenie praescriptio, oddając je wyrażeniem przedawnienie kanoniczne. To dookreślenie pojęcia „przedawnienia” przymiotnikiem „kanoniczne” z pewnością wskazywałoby na odrębność i pewną specyfikę instytucji w porównaniu z tą, która funkcjonuje w polskim obrocie prawnym i w polskim języku prawnym i prawniczym ${ }^{46}$.

\section{Konstrukcja prawna}

2.1. Marzenie o koncepcji ogólnej przedawnienia w nauce prawa zrealizowana idea w prawie kanonicznym?

Ogólna teoria prawa żywi nadzieję na wypracowanie takiej koncepcji uogólniającej przedawnienia, że byłoby możliwe rozciągnięcie jej na cały system prawny. Marzący o takiej regulacji prawnej teoretycy prawa chcą bowiem, aby były jednakowe, a przynajmniej wspólne w większości, normy dotyczące przedawnienia - tak w prawie cywilnym, jak administracyjnym czy karnym. Tym wszak, co łączy, jest upływ czasu, który wpływa na treść stosunków prawnych. Niestety, jak dotąd, ogólnej doktrynie prawa nie udało się wypracować takiego uogólniającego konceptu przedawnienia ${ }^{47}$.

\footnotetext{
${ }^{44}$ Zob. W. Aymans, K. Mörsdorf, Kanonisches Recht..., s. 503; H. Socha, Komentarz do kan. 197-199..., passim; F. Рототsching, Rechtspersönlichkeit..., s. 148.

${ }^{45}$ Tak np. Th. O. Martin, Adverse Possession ..., passim, już choćby w samym tytule książki. Jednakże zrezygnował z tego zabiegu PH. J. Brown, Prescription ..., passim.

${ }^{46}$ Stąd w artykule konsekwentnie używa się wyrażenia przedawnienie kanoniczne, żeby oddać w języku polskim instytucję, znaną w prawie kanonicznym pod łacińskim pojęciem praescriptio.

${ }^{47}$ Por. B. Kordasiewicz, Problematyka dawności..., s. 528-529, nb. 1.
} 
Tymczasem nauka prawa kanonicznego, w ramach prac nad Kodeksem Prawa Kanonicznego z 1983 r., podjęła się próby stworzenia wspólnej regulacji prawnej przedawnienia dla całego Kodeksu Kościoła łacińskiego. W ten sposób powstał Tytuł X Księgi I Normy ogólne w tymże Kodeksie, zatytułowany De praescriptione ${ }^{48}$. Wydawałoby się zatem, że nauce prawa kanonicznego udało się to, o czym tylko marzy ogólna teoria prawa.

Jednakże już norma zawarta w kan. 197 KPK (kan. 1540 KKKW) ogranicza swój zakres przedmiotowy do instytucji prawa cywilnego, o czym była mowa. Kanonizacja ustawy cywilnej bowiem dotyczy tylko instytucji dawności. Nie dotyczy zaś przedawnienia w prawie administracyjnym czy karnym poszczególnych porządków prawnych państwowych. Co więcej, kan. 197 KPK nie może być stosowany do przedawnienia kanoniczno-karnego, o którym mowa w kan. 1362 KPK. Wobec powyższego trzeba stwierdzić, że kan. 197 KPK nie ma charakteru uogólniającego, gdyż zakres jego zastosowania jest ograniczony.

Natomiast charakter uogólniający ma kan. 198 KPK (kan. 1541 KKKW), który przewiduje wymóg dobrej wiary przez cały czas biegu terminu przedawnienia. Przepis ten ma zastosowanie zasadniczo do wszystkich przypadków przedawnienia kanonicznego. Jednakże i w tym zakresie nie udało się ujednolicić ustawodawstwa kanonicznego, gdyż przewidziano jeden wyjątek - przedawnienie kanoniczno-karne. Wyjątek ten był podyktowany względami natury przedawnienia w sprawach karnych ${ }^{49}$.

\footnotetext{
${ }^{48} \mathrm{~W}$ trakcie bowiem posiedzenia coetusu De bonis Ecclesiae temporalibus zauważono, że kan. 1508-1512 KPK z 1917 r. nie powinny znajdować się w księdze De rebus, ale w Normach ogólnych. Por. Coetus studiorum de Iure Patrimoniali Ecclesiae, De Iure Patrimoniali Ecclesiae, Communicationes 5(1973), nr 1, s. 95-96, n. 9. Zob. również J. Miñambres, Komentarz..., s. 1084. Z tych też względów kan. 1508, 1509 i 1512 KPK z 1917 r. zostały przeniesione z miejsca poświeconego w Kodeksie dobrom doczesnym Kościoła do norm ogólnych, stanowiąc dziś odpowiednio kan. 197, 199 i 198 KPK z 1983 r. (kan. 1540, 1542 i 1541 KKKW z 1990 r.).

${ }^{49}$ Por. F. Рототsching, Rechtspersönlichkeit..., s. 148, przyp. 42.
} 
W końcu kan. 199 KPK (kan. 1542 KKKW) reguluje przedmioty wyłączone spod instytucji przedawnienia kanonicznego. Ratio legis tego postanowienia jest teologiczna ${ }^{50}$, stąd też specyfika tego unormowania. Norma zawarta w kan. 199 KPK nie ma jednak charakteru uogólniającego, jakkolwiek dotyczy ogółu przepisów Kodeksu. Nie wyciąga bowiem z szeregu tych kanonów jakiejś ogólnej zasady, lecz wszystkie wyjątki - które równie dobrze mogłyby znaleźć miejsce przy okazji stanowienia poszczególnych instytucji prawnokanonicznych - zbiera $\mathrm{w}$ jednym kanonie.

Podsumowując, po analizie kanonów zawartych we wspomnianym Tytule X Księgi I wydaje się, że - poza zmianą w systematyce przepisów Kodeksu Prawa Kanonicznego z 1983 r. - nic się w zasadzie nie zmieniło, a samemu ustawodawcy kościelnemu nie udało się to, o czym marzą teoretycy prawa. Z wyjątkiem kan. 198 KPK (kan. 1541 KKKW), który rzeczywiście ma charakter uogólniający, pozostałe kanony tego tytułu dotyczą partykularnych zagadnień przedawnienia kanonicznego. Jak bowiem słusznie zauważono w literaturze kanonistycznej $^{51}$, przedawnienie kanoniczne nie jest instytucją jednorodną. Nawet jeżeli przyjąć, że ustawodawcy kościelnemu udało się po części stworzyć ogólną instytucję przedawnienia kanonicznego, to z pewnością dzieło to pozostawia jeszcze dużo do życzenia.

\subsection{Model dawności w prawie cywilnym polskim}

W literaturze cywilistycznej zauważono, że z punktu widzenia ekonomicznego konsekwencje dawności - czy to jako przedawnienia nabywczego, czy też umarzającego - są wielce zbliżone. Oto bowiem

\footnotetext{
${ }^{50}$ Przepis kan. 199 KPK wyłącza spod przedawnienia kanonicznego następujące materie: prawa i obowiązki wynikające z prawa Bożego, uprawnienia z przywileju apostolskiego, prawa i obowiązki związane bezpośrednio z życiem duchowym wiernych, stypendia i zobowiązania mszalne, powierzenie urzędu kościelnego, którego wykonywanie zgodnie z przepisami prawa wymaga święceń. Ponadto mowa jest o dwóch przedmiotach wyłączonych spod przedawnienia kanonicznego, mających na celu dyscyplinę kościelną - ustalone i niewątpliwe granice okręgów kościelnych oraz prawo wizytacji i obowiązek posłuszeństwa.
}

${ }^{51}$ Zob. A. Stankiewicz, De „,canonizatione”..., s. 352, cytując P. Gismondiego. 
nowy podmiot prawny uzyskuje korzyść ekonomiczną kosztem majątku dotychczas uprawnionego wskutek odmowy ochrony prawnej dotąd uprawnionemu. Jednakże efekt ten jest skutkiem zastosowania różnych konstrukcji (modeli) prawnych dawności w prawie cywilnym ${ }^{52}$.

Jak już była o tym mowa, w polskim prawie cywilnym należy odróżnić przedawnienie, termin zawity i zasiedzenie wraz z przemilczeniem. Przedawnienie w naszym prawie cywilnym powoduje, że zobowiązanie przekształca się z zupełnego w naturalne (obligatio naturalis), a zatem przedawnione roszczenie nie wygasa ${ }^{53}$. Konsekwentnie, upływ terminu przedawnienia nie może być uwzględniany przez sąd z urzędu, a tylko na zarzut podniesiony przez stronę $e^{54}$.

Prekluzja, czyli termin zawity, ma szerszy zakres, tzn. nie dotyczy tylko praw majątkowych (jak przedawnienie). Ponadto upływ terminu zawitego powoduje - w przeciwieństwie do przedawnienia - wygaśnięcie roszczenia lub samego prawa czy uprawnienia ${ }^{55}$. Stąd upływ tego rodzaju terminu sąd powinien uwzględnić $z$ urzędu ${ }^{56}$, a nie na zarzut podniesiony przez stronę przeciwną.

W końcu zasiedzenie jako przedawnienie nabywcze prowadzi do nabycia prawa podmiotowego z mocy samego prawa, ipso iure, z chwilą upływu ostatniego dnia terminu zasiedzenia ${ }^{57}$. Nabycie prawa przez zasiedzenie ma charakter pierwotny ${ }^{58}$. Do tego czasu posiadacz samoistny rzeczy nie ma do niej żadnego prawa, gdyż zasiedzenie „nie

${ }^{52}$ Por. B. Kordasiewicz, Problematyka dawności..., s. 530, nb. 5.

${ }^{53}$ Zob. tamże, s. 535, nb. 19. Podobnie na gruncie prawa anglosaskiego, a ściślej rzecz biorąc amerykańskiego, por. Рн. J. Brown, Prescription ..., s. 384-388, 394-397.

${ }^{54}$ Por. B. Kordasiewicz, Problematyka dawności..., s. 536, nb. 20.

${ }^{55}$ Por. Z. Radwański, Prawo cywilne..., s. 229, nb. 736.

${ }^{56}$ Zob. B. Kordasiewicz, Problematyka dawności..., s. 536, nb. 20; Z. RADWAŃSKI, Prawo cywilne..., s. 230-231, nb. 740.

${ }^{57}$ Por. art. 112 zd. 1 k.c.

${ }^{58}$ Zob. A. KunICKI, Zasiedzenie..., s. 65-67; E. JANECZKo, Zasiedzenie, Warszawa 1996, s. 6 (obie pozycje cytują literaturę dotyczącą tego zagadnienia); Z. RADwAŃsKI, Prawo cywilne..., s. 82, nb.195. Stanowisko, że nabycie prawa w drodze zasiedzenia ma charakter nabycia pierwotnego, reprezentowali wcześniej w polskiej literaturze cywilistycznej: Fr. Zoll, J. Wasilkowski, A. Szpunar, A. Wolter, S. Szer (por. literaturę tychże autorów, przytoczoną we wcześniej podanych pozycjach). 
narasta" wraz z upływem czasu ${ }^{59}$. Nabycie własności przez zasiedzenie następuje nieodpłatnie, co wynika z pierwotnego charakteru tego nabycia. Nabywca prawa przez zasiedzenie nie ma obowiązku spełnienia jakiegokolwiek świadczenia na rzecz poprzedniego właściciela, zwłaszcza z bezpodstawnego wzbogacenia (por. art. 405 i nast. k.c.) ${ }^{60}$.

2.3. Model przedawnienia kanonicznego w kan. 197 KPK (kan. 1540 KKKW) na tle prawnoporównawczym

\subsubsection{Założenia idealne modelu}

W założeniu idealnym modelu przedawnienia kanonicznego, o którym mowa w kan. 197 KPK (kan. 1540 KKKW), te wyżej opisane modele dawności w polskim prawie cywilnym zostały kanonizowane. Jak już była o tym mowa, wyrażenie modum iuris subiectivi acquirendi vel amittendi necnon ab obligationibus sese liberandi (,sposób nabycia lub utraty prawa podmiotowego, jak również uwolnienia się od zobowiązań”) dotyczy przedawnienia nabywczego (zasiedzenia), jak również przedawnienia umarzającego (przedawnienia i terminów zawitych). Co więcej, cały Tytuł X Księgi I KPK dotyczy wszelkich praw, o których mowa w prawie kanonicznym, z wyjątkiem materii wyłączanych spod przedawnienia kanonicznego w kan. 199 KPK. Jednym słowem, w swoich założeniach teoretycznych model przedawnienia kanonicznego przewiduje kanonizację wszelkich instytucji prawa cywilnego, które odpowiadają polskiej instytucji dawności, a ponadto

${ }^{59}$ Przykładowo, nikt nie staje się „,bardziej” właścicielem po upływie 10 lat. Posiadanie jest czystym stanem faktycznym, stąd nie rodzi żadnych praw, a poza tym w prawie polskim nie korzysta z ochrony publicjańskiej; por. A. KunICKI, Zasiedzenie..., s. 15, 68; J. Ignatowicz, Ochrona posiadania, Warszawa 1963, s. 246-251; Tenże, Prawo rzeczowe..., s. 293.

${ }^{60}$ Por. A. Ohanowicz, Niestuszne wzbogacenie, Warszawa 1956, s. 155 (przedstawienia stanu prawa niemieckiego), s. 174-175; A. KunICKI, Zasiedzenie..., s. 80; J. ST. PiĄtowski, Glosa do postanowienia Sądu Najwyższego z 15.11.1968, Orzecznictwo Sądów Polskich i Komisji Arbitrażowych 1970, nr 1, poz. 5, s. 19; Tenże, w: System prawa cywilnego, t. II, Wrocław 1977, s. 340; E. JANECZKo, Zasiedzenie ..., s. 143-144. 
obejmuje wszelkie inne szeroko pojęte prawa, które można nabyć lub utracić wskutek upływu czasu według prawa kanonicznego ${ }^{61}$.

\subsubsection{Trudności z zastosowaniem teoretycznych założeń modelowych}

Taki model przedawnienia kanonicznego budzi wiele wątpliwości na tle kanonizowanych ustaw cywilnych. Model ten bowiem - paradoksalnie - jest i za szeroki, i jednocześnie za wąski (sic!). Za szeroki - gdyż w zamyśle (nieudanym) ustawodawcy kościelnego miał on dotyczyć też przedawnienia karno-kanonicznego, ale to z kolei zostało wyłączone spod zakresu hipotezy normy prawnej wyrażonej w kan. 197 KPK (kan. 1540 KKKW), która kanonizuje tylko prawo cywilne, a nie prawo karne państwowe. Poza tym model ten jest za wąski, gdyż z trudnością mieszczą się w nim różne systemy prawa cywilnego obowiązujące we współczesnym świecie, nie wyłączając - jak się okaże - polskiego prawa cywilnego.

W rozwoju historycznym w Europie wykształciły się wszakże dwa systemy ochrony prawnej - anglosaski i kontynentalny. W systemie Common Law bazuje się na koncepcji skargi, która wprost wywodzi

${ }^{61} \mathrm{~W}$ literaturze niemieckojęzycznej odróżnia się od przedawnienia umarzającego cywilnoprawną instytucję terminu zawitego, zauważając, że dotyczy ona utraty prawa (decadentia), które już od początku jest ograniczone czasowo, a sam termin zawity może być ustanowiony nie tylko w ustawie, lecz również postanowieniem sędziego czy też przez same strony procesowe. Taki termin zawity nie podlegałby zatem regulacji o wymogu dobrej wiary i niemożliwe by było przerwanie biegu takiego terminu. Por. H. Socha, Komentarz do kan. 197-199..., 197/2, t. 6. Z tą tezą zgodzić się nie można, biorąc pod uwagę, że prawo kanoniczne kanonizuje w kan. 197 KPK wszystkie instytucje objęte polskim terminem dawności, także terminy zawite (por. A. STANKIEwicz, De ,canonizatione”..., s. 351-360, co też powołuje H. Socha, Komentarz do kan. 197-199..., 197/3, t. 11). Natomiast skutki, o których mowa jest w odniesieniu do terminu zawitego, można osiągnąć poprzez właśnie kanonizację ustawy cywilnej, z wyjątkiem wyłączenia wymogu dobrej wiary w przypadku terminu zawitego. Przesłanka dobrej wiary z kan. 198 KPK ma bowiem charakter ogólny i teologiczny (z prawa Bożego), stąd rozciąga się na wszystkie instytucje dawności, a wyjątek przewidziany w kan. 198 KPK powinien być interpretowany zawężająco (kan. 18 KPK). 
się z rzymskiej actio. Natomiast system kontynentalny odwołuje się do pojęć praw podmiotowych i wywodzących się z nich roszczeń6 ${ }^{62}$.

Stanowienie w kan. 197 KPK (kan. 1540 KKKW) o prawach podmiotowych jest wyraźnym nawiązaniem tylko do systemu kontynentalnego ochrony prawnej. Pozostawia on zatem pod znakiem zapytania koncepcję przedawnienia kanonicznego zawartą w kan. 197 KPK na gruncie prawa Common Law, które tam ma formę czysto procesową, a nie materialnoprawną. Tymczasem kan. 197 KPK operuje pojęciami $\mathrm{z}$ dziedziny prawa materialnego, nie zaś procesowego. Prawo procesowe w kan. 197 KPK nie zostało kanonizowane ${ }^{63}$. Stąd wydaje się, że na gruncie Common Law bardziej poprawne byłoby odsyłanie do kan. 1492 KPK (przedawnienie skarg procesowych) w celu rozwiązania problemu przedawnienia w dziedzinie zobowiązań ${ }^{64}$.

To jednak, że kan. 197 KPK (kan. 1540 KKKW) wyraźnie nawiązuje do systemu kontynentalnego ochrony prawnej, nie uchroniło ustawodawcy kościelnego od problemów z wykładnią tegoż kanonu w zderzeniu z europejskimi systemami prawa cywilnego, zwłaszcza z niemieckim, polskim i hispańskim.

${ }^{62}$ Por. B. Kordasiewicz, Problematyka dawności..., s. 537, nb. 21; Рн. J. Brown, Prescription..., s. 398 (w odniesieniu jednak tylko do instytucji statute of limitations). Co ciekawe, to odmienne podejście do zagadnienia przedawnienia kanonicznego widoczne jest w literaturze kanonistycznej przedmiotu. Wśród autorów kręgu anglosaskiego widać wyraźne ,procesualistyczne” ujęcie zagadnienia; autorzy ci traktują bardziej o skardze procesowej niż o prawie podmiotowym; zob. PH. J. Brown, Prescription ..., passim.

${ }^{63} \mathrm{O}$ wykładni pojęć w kan. 197 KPK, pod rządem kan. 1508 KPK z 1917 r., zob. O. Cassola, La recezione del Diritto Civile nel Diritto Canonico, Roma 1969, s. 104.

${ }^{64}$ Trzeba jednak zaznaczyć, że taki pogląd w literaturze kanonistycznej kręgu kultury Common Law nie został wyrażony (odpowiednio: kan. 197 KPK należy zastosować do limitation of actions, czyli do przedawnienia), jakkolwiek podkreślono, że limitation of actions ma tam charakter procesowy, a nie materialnoprawny; por. TH. O. Martin, Adverse Possession..., s. 3. Poprzednio obowiązujący kan. 1701 KPK z 1917 r., odpowiednik obecnego kan. 1492 KPK, odsyłał w tym zakresie do przepisów kanonizujących ustawę cywilną. Obecny kan. 1492 KPK enigmatycznie stanowi o przedawnieniu ad normam iuris, nie precyzując tej normy prawnej (kanoniczna czy kanonizowana?). Por. A. Stankiewicz, De „,canonizatione”..., s. 353, przyp. 71. 
W niemieckiej literaturze kanonistycznej podniesiono - słusznie zastrzeżenie do konstrukcji przedawnienia kanonicznego sformułowanej w kan. 197 KPK $^{65}$. Na gruncie k.c. niemieckiego z 1896 r. przedawnieniu podlegają nie prawa (Rechte), lecz roszczenia (Ansprüche) ${ }^{66}$. Natomiast kan. 197 KPK (kan. 1540 KKKW) za przedmiot przedawnienia uznaje prawo podmiotowe (ius subiectivum) ${ }^{67}$, a w następnych kanonach - prawo jako takie i obowiązki (iura et obligationes - por. kan. 199, n. 1, 2, 3, 7 KPK i odpowiednio te numery w kan. 1542 KKKW).

Zastrzeżenie podniesione przez kanonistykę niemiecką dotyczy również polskiego stanu prawnego, który w tym zakresie jest wzorowany na niemieckim prawie cywilnym ${ }^{68}$.

W końcu problem pojawia się też w k.c. hiszpańskim z 1889 r., gdzie przedmiotem przedawnienia są prawa i roszczenia (los derechos $y$ las acciones ${ }^{69}$. Zatem podniesiona przez kanonistów niemieckich

${ }^{65}$ Zob. W. Aymans, K. Mörsdorf, Kanonisches Recht..., s. 504.

${ }^{66}$ Por. $§ 194$, I k.c. niemieckiego, który brzmi: „Das Recht, von einem anderen ein Tun oder Unterlassen zu verlangen (Anspruch), unterliegt der Verjährung" (kursywa P.S.). Roszczenie to uprawnienie żądania od zobowiązanego jakiegoś działania lub zaniechania. Stąd nie podlegają przedawnieniu - według tego modelu - pozostałe prawa, jak np. dobra osobiste czy uprawnienia kształtujące (czyli jednostronnego wpływania na zmianę lub ustanie stosunku prawnego, np. do wypowiedzenia czy odstąpienia od umowy). Zob. H. SocHA, Komentarz do kan. 197-199..., 197/8, t. 26; co do polskiego prawa cywilnego w podobny sposób, por. choćby: Z. RADWAŃSKi, Prawo cywilne..., s. 69-75, nb. 144-167.

${ }^{67}$ Wyrażenie łacińskie modum iuris subiectivi acquirendi vel amittendi necnon ab obligationibus sese liberandi z kan. 197 KPK można rozumieć w ten sposób, że iuris subiectivi dotyczy nie tylko sposobu nabycia czy utraty, ale też uwolnienia się od zobowiązań. Zmiana redakcyjna w kan. $1540 \mathrm{KKKW}$ podkreśla tylko tego typu interpretację, gdyż wyrażenie iuris subiectivi... modum wiąże klamrowo całą frazę (,... tamquam iuris subiectivi acquirendi vel amittendi necnon ab obligationibus se liberandi modum..." - kursywa P.S.).

${ }^{68}$ Zob. art. 117 § 1 k.c.: „Z zastrzeżeniem wyjątków w ustawie przewidzianych roszczenia majątkowe ulegają przedawnieniu” (kursywa - P.S.).

${ }^{69}$ Por. art. 1930 k.c. hiszpańskiego: „Por la prescripción se adquieren, de la manera y con las condiciones determinadas en la ley, el dominio y demás derechos reales. También se extinguen del propio modo por la prescripción los derechos y las acciones, de cualquier clase que sean" (kursywa - P.S.). Jednakże cały rozdział III tytułu XVIII 
trudność, dotycząca zastosowania kan. 197 KPK (kan. 1540 KKKW), jest również aktualna pod rządem hiszpańskiego prawa cywilnego: roszczenia bowiem nie są literalnie przedmiotem przedawnienia kanonicznego w kan. 197 KPK (kan. 1540 KKKW).

Podobnych kłopotów nie rodzą na gruncie kan. 197 KPK te systemy prawa cywilnego, które przewidują przedawnienie praw, tj. k.c. francuski z 1804 r. ${ }^{70}$, k.c. austriacki z 1811 r. ${ }^{71}$ oraz k.c. włoski z 1942 r. ${ }^{72}$.

\subsubsection{Wnioski}

Podsumowując, należy stwierdzić, że zgodnie z zamysłem ustawodawcy kościelnego model przedawnienia obecny w kan. 197 KPK obejmuje - jakkolwiek niedoskonale - wszystkie możliwe konstrukcje prawne tej instytucji prawnej w ustawodawstwach cywilnych. Jak już była bowiem o tym mowa, samo pojęcie przedawnienia kanonicznego nie jest jednorodne, tym bardziej więc różnorodność tę powinna uwzględniać kanonizacja przepisów prawa cywilnego w tym zakresie.

Dlatego wydaje się, że redakcja przepisu kan. 197 KPK nie jest doskonała. Ustawodawca kościelny, używając wyrażenia ius subiectivum, niepotrzebnie wywołał wątpliwości na gruncie szeregu kodeksów

księgi IV k.c. hiszpańskiego dotyczy przedawnienia roszczeń (De la prescripción de las acciones).

${ }^{70}$ Art. 2219 k.c. francuskiego: „La prescription extinctive est un mode d'extinction d'un droit résultant de l'inaction de son titulaire pendant un certain laps de temps" (kursywa - P.S.). Dokładnie o relacji prawa cywilnego francuskiego do prawa kanonicznego (co prawda pod rządem KPK z 1917 r.) zob. R. NAz, Prescription, w: Dictionnaire de droit canonique, red. R. Naz, t. 7, Paris 1965, kol. 178-194.

$71 \mathrm{~W} \S 1451$ k.c. austriackiego stanowi się: „Die Verjährung ist der Verlust eines Rechtes, welches während der von dem Gesetze bestimmten Zeit nicht ausgeübt worden ist" (kursywa-P.S.).

${ }^{72}$ Ustawodawca włoski stanowi w art. 2934 ust. 1 k.c.: „Ogni diritto si estingue per prescrizione, quando il titolare non lo esercita per il tempo determinato dalla legge" (kursywa - P.S.). Zestaw ustawodawstw europejskich w zakresie przedawnienia, zob. A. Stankiewicz, De „,canonizatione”..., s. 353. Należy też zauważyć, że z wyjątkiem przedmiotu przedawnienia kodeksy cywilne w systemie kontynentalnym zazwyczaj reprezentują tę samą klasyczną konstrukcję prawną: przedawnienie w sensie ścisłym jest uwzględniane na zarzut strony, a nie z urzędu. 
cywilnych europejskich (w tym polskiego) ${ }^{73}$, a zupełnie nie wziął pod uwagę - z teoretycznego punktu widzenia - rzeczywistości prawnej systemów anglosaskich, w których problem rozwiązuje się na poziomie procesowym, a nie prawa materialnego. W każdym razie możliwa jest też i taka wykładnia kan. 197 KPK, która wyrażenie ius subiectivum odniosłaby jedynie do przedawnienia nabywczego, uznając, że z kolei wyrażenie modum... ab obligationibus sese liberandi dotyczy przedawnienia umarzającego. W ten sposób zwrot ius subiectivum nie byłby łączony z tym ostatnim typem przedawnienia. To z kolei ułatwiłoby kompatybilność prawa cywilnego wielu krajów (m.in. polskiego) z prawem kanonicznym. Niezależnie od tego pozostaje nadal problem teoretycznoprawny kanonizacji limitation of actions w systemie prawnym Common Law.

\section{Uzasadnienie legislacyjne przedawnienia kanonicznego na podstawie kan. 197 KPK (kan. 1540 KKKW)}

Omówienie teoretycznoprawne koncepcji przedawnienia kanonicznego, nawet jeśli dokonane na szerokim tle prawnoporównawczym, nie byłoby pełne bez postawienia pytania o sens tej instytucji. Instytucja przedawnienia bowiem została przejęta przez ustawodawcę kościelnego z prawa rzymskiego z różnych powodów ${ }^{74}$. Racje te wpłynęły

${ }^{73} \mathrm{Z}$ inną krytyką tego sformułowania wystąpił C. REDAELLI, Trascorrere del tempo..., s. 236, twierdząc - słusznie - że verba legis kan. 1508 KPK z 1917 r. (Praescriptionem, tanquam acquirendi et se liberandi modum, ...) były poprawniejsze, gdyż pozbawione wyrażenia iuris subiectivi, które - na przykład - nie mają sensu w przypadku przywileju (por. kan. 82 KPK z 1983 r.). Zgadzając się z tym Autorem co do zasady, nie można jednak podzielić jego poglądu, że kan. 197 KPK miałby ogólne zastosowanie do przedawnienia kanonicznego. Wbrew intencji ustawodawcy kanonicznego, który przesunął ten przepis z księgi o dobrach doczesnych Kościoła, reguluje on tylko zagadnienie kanonizacji ustaw cywilnych, a nie w ogóle przedawnienie kanoniczne. Lepiej zatem by się stało, gdyby kan. 197 KPK pozostał w Księdze V.

${ }^{74}$ Por. R. Naz, Prescription..., kol. 178; S. Sanz Villalba, Los elementos éticos de la prescripción romana y su aceptación en el fuero eclesiástico hasta el Decreto de Graciano, Revista española de Derecho canónico 3(1948), s. 35-59; J. Miñambres, Komentarz do kan. 197-199..., s. 1084; A. GAUTHIER, Roman Law and its Contribution to the Development of Canon Law, Ottawa 1996, s. 59-62; R. H. Helmholz, The 
- oczywiście - na kształt konstrukcji prawnej samego przedawnienia kanonicznego.

Przede wszystkim przedawnienie kanoniczne, o którym mowa w kan. 197 KPK (kan. $1540 \mathrm{KKKW})^{75}$ - podobnie jak ta instytucja w prawie cywilnym - ma zapewnić pewność prawa, pozwolić uniknąć problemów dowodowych, zmobilizować opieszałych w wykonywaniu ich praw, a nade wszystko zapewnić pokój we wspólnocie zgodnie z zasadą quieta non movere ${ }^{76}$. Ta pewność prawa jest tak ważną wartością, że w orzecznictwie rotalnym podniesiono, iż sędzia nie może mieć sumienia pewniejszego niż wtedy, kiedy oprze się na dowodzie jak najbardziej obiektywnym, tym zaś - i to w sposób najznamienitszy (luculentissimum) - jest przedawnienie ${ }^{77}$. To zatem dobro publiczne, a nie indywidualne, leży u podstaw przedawnienia (także kanonicznego $)^{78}$. A zatem stanowiąc wymóg dobrej wiary ${ }^{79}$, przesłankę przecież

Spirit..., s. 174-199. Ponadto jasne jest w literaturze kanonistycznej od początku, że przedawnienie nie jest instytucją wywodzącą się z prawa naturalnego (por. w Dekrecie Gracjana glossa ordinaria do c. 16, q. 3, c. 4, cytowana przez R. H. Helmholz, tamże, s. 436, nota 13: „nam de iure naturali non sunt praescriptiones inductae”).

${ }^{75} \mathrm{~W}$ tym miejscu należy przypomnieć, że całkiem odmienną ratio legis wskazuje się przy przedawnieniu karno-kanonicznym, co w literaturze kanonistycznej stanowi poważny argument dla odrębnego traktowania tegoż przedawnienia w prawie kanonicznym; zob. Ph. J. Brown, Prescription..., s. 436-439.

${ }^{76}$ Co do uzasadnienia dawności w prawie cywilnym por. B. Kordasiewicz, Problematyka dawności..., s. 539-543, nb. 22-30. Na gruncie prawa anglosaskiego - co oczywiste - podkreśla się bardziej aspekt procesowy przedawnienia, $\mathrm{tj}$. proceduralną uczciwość (fair play) wobec pozwanego, wskazując jednocześnie na wymiar ekonomiczny i społeczny przedawnienia, które ma na celu chronić aktywność gospodarczą w społeczności; por. PH. J. Brown, Prescription..., s. 436. Co do prawa kanonicznego zob. C. Redaelli, Trascorrere del tempo..., s. 233-234; R. SobańsKi, Komentarz do kan. 197-199..., s. 286; V. De Paolis, A. D’Auria, Le Norme Generali..., s. 493-494.

${ }^{77},[\ldots]$ animum iudicis securiorem consistere in argumento magis obiectivo quod habetur luculentissimum in praescriptione" (S. Romana Rota, decisio coram M. Lega, Michoacan., 7.01.1913, S. Romanae Rotae Decisiones seu Sententiae 5 [1913], s. 18, n. 16).

${ }^{78}$ Zob. tamże, s. 18-19, n. 17.

${ }^{79}$ Por. Vigilanti Aleksandra II (1159-1181), stanowiący w zasadzie wyciąg z reskryptu tegoż papieża do arcybiskupa Slaerno (c. 5, X, de praescript., II, 26); Quoniam omne Innocentego III (1198-1216) wydany w trakcie Soboru Laterańskiego IV w 1215 r. i stanowiący jego can. 41 (c. 20, X, de praescript., II, 26). 
teologiczną, nauczanie papieskie rozumie to dobro publiczne inaczej niż współcześni ustawodawcy świeccy ${ }^{80}$.

Nieuchronnie wzmianka o wymogu dobrej wiary przy przedawnieniu kanonicznym doprowadzić musi do wskazania różnic w samym fundamencie czy podstawie prawa kanonicznego i prawa świeckiego. O ile bowiem prawo świeckie zmierza do zapewnienia pokoju między obywatelami państwa (i taki też ma cel instytucja dawności w prawie cywilnym), o tyle celem ostatecznym prawa kanonicznego jest zbawienie dusz (por. kan. $1752 \mathrm{KPK})^{81}$. Dlatego też prawo kanoniczne wymaga dobrej wiary jako przesłanki przedawnienia kanonicznego, opierając się na zasadzie, non est ex fide, peccatum est ${ }^{82}$. Zbieżne bowiem z prawem cywilnym świeckim cele przedawnienia kanonicznego nie mogły wszakże przesłonić wymogów teologicznych.

\section{Zakończenie}

Koncepcja teoretyczna przedawnienia kanonicznego, oparta na kanonizacji świeckiej ustawy cywilnej, o której mowa w kan. 197 KPK (kan. $1540 \mathrm{KKKW}$ ), nie nasuwa większych trudności na gruncie polskiego prawa cywilnego. Jak była o tym wyżej mowa, z punktu widzenia techniki legislacyjnej można mieć - uzasadnione - zastrzeżenia co do języka kodeksów łacińskiego i wschodniego prawa kanonicznego, które nie do końca uwzględniły założenia teoretycznoprawne wszyst-

${ }^{80}$ Zagadnienie wymogu dobrej wiary przekracza ramy niniejszego opracowania ograniczonego do kan. 197 KPK. Komentarz do kan. 198 KPK (kan. 1541 KKKW), dotyczącego dobrej wiary w przedawnieniu kanonicznym, zob. w innym artykule: P. SKonieczny, Przesłanki przedawnienia kanonicznego, ze szczególnym uwzględnieniem kanonizowanej ustawy cywilnej polskiej, oddane do druku w „Prawie Kanonicznym".

${ }^{81}$,Dicendum, quod circa hoc est contrarietas iuris civilis et canonici: quia secundum ius civile talis praescriptio tenet, secundum ius canonicum talis praescribere non potest. Et ratio huius contrarietatis est, quia alius est finis quem intendit civilis legislator, scilicet pacem servare et stare inter cives, quae impediretur, si praescriptio non curreret; quicumque enim vellet, posset venire, et dicere: istud fuit meum quocumque tempore. Finis autem iuris canonici tendit in quietem Ecclesiae, et salutem animarum" (św. Tomasz z AkwInu, Quodlibetum XII, q. 16, art. 2, corp.; kursywa - P.S.).

${ }^{82}$ Cytat z wyżej powoływanego dekretału Quoniam omne. 
kich obowiązujących systemów prawa cywilnego we współczesnym świecie. Ponadto $\mathrm{z}$ formalnego punktu widzenia można podnosić zarzuty odnośnie do systematyki kodeksowej (tj. umieszczenia kan. 197 KPK wśród przepisów Księgi I). W końcu, w polskim kontekście prawnym wątpliwości budzi pojęcie praescriptio, które - jak wykazano - rodzi problemy z jego przekładem (i rozumieniem) w polskim języku prawniczym. Z pewnością zaś pojęcie to nie odpowiada polskiemu terminowi przedawnienie, jak z kolei chcą autorzy oficjalnego przekładu KPK na język polski.

Ostatecznie stwierdzić by można, że opisany wyżej model przedawnienia kanonicznego, o którym mowa w kan. 197 KPK (kan. 1540 KKKW), jest zbliżony do instytucji dawności w polskim prawie cywilnym. Jednakże to stwierdzenie byłoby zbyt pochopne, gdyż oparte jedynie na formalnoprawnym aspekcie konstrukcji przedawnienia kanonicznego. Ta formalna płaszczyzna jednak nie wystarcza i trzeba się odnieść do aspektu realnego, czyli teologicznego, samego prawa kanonicznego ${ }^{83}$. Bez tej korekty nie jest możliwe właściwe ujęcie komentowanej instytucji prawnokanonicznej.

Ta teologiczna korekta została wyrażona w kan. 198 KPK, wprowadzając do przedawnienia kanonicznego wymóg dobrej wiary rozumianej teologiczno-prawnie. W rezultacie każda instytucja prawa kanonicznego, także przedawnienie kanoniczne, jakkolwiek zbliżone konstrukcyjnie do instytucji dawności w prawie świeckim - będzie, przynajmniej w swojej ratio legis, wykazywało różnicę fundamentalną, a sprowadzającą się do celu każdej normy kanonicznej - zbawienia dusz (por. kan. $1752 \mathrm{KPK}$ ).

${ }^{83}$ Sam aspekt formalny byłby, zwłaszcza w teorii prawa kościelnego, niewystarczający. W teorii prawa świeckiego podnosi się bowiem postulat tzw. „wielopłaszczyznowości” teorii prawa, mając na myśli aspekty realne prawa, tj. jego aspekty socjologiczne, psychologiczne $\mathrm{i}$ inne, związane $\mathrm{z}$ genezą i obowiązywaniem norm prawnych (por. Z. Ziembiński,w: A. Redelbach, S. Wronkowska, Z. Ziembiński: Zarys teorii państwa i prawa, Warszawa 1992, s. 10-11, 19). Aspektem realnym prawa kanonicznego byłaby zatem rzeczywistość teologiczna, czyli po prostu teologia. 


\section{The Concept of the Canonical Prescription.}

\section{Legal Comparison and Theoretical Observations on can. 197 CIC/83 (can. 1540 CCEO), with Particular Consideration of the Polish Canonized Law}

The author studies the concept of the canonical prescription in relation to Polish civil law. He notes straightaway that the term "praescriptio" found in the title of Book I, Title X and in canons 198 and 199 of the 1983 Code of Canon Law does not have the same meaning as we find in canon 197, because the latter confines itself to what is in civil law (to the so-called "dawnośc'" in Polish). He therefore intends not to translate it into Polish or to add the adjective "canonical" to the word "prescription". He then analyses the various models of prescription to be found in civil law systems, and he criticises the term "iuris subiectivi" as the object of prescription as stated in canon 197 of the 1983 Code. According to the author, the transfer of canon 197 of the 1983 Code from Book $\mathrm{V}$ is a mistake. 